\title{
Aspects of the ecology and population genetics of the bivalve Corbula gibba
}

\author{
Sebastian P. Holmes*, Nicola Miller \\ Port Erin Marine Laboratory, Port Erin, Isle of Man IM9 6JA, British Isles
}

\begin{abstract}
The bivalve mollusc Corbula gibba (Olivi) is often regarded as an invasive weed species that forms monospecific stands in organically enriched hypoxic habitats. However, despite its status as a potential menace, surprisingly little is known about its basic biology, including its dispersal capacity. Measurement of the respiration rate of C. gibba revealed a respiratory demand of $3.12 \mu \mathrm{l} \mathrm{O}_{2}$ $\mathrm{h}^{-1}$ and a respiratory quotient of 0.61 , which suggests that $C$. gibba adopts a conservationist rather than exploitative mode of life. Examination of the hypoxic tolerance of C. gibba determined that adults could survive for $>34 \mathrm{~d}\left(\mathrm{LT}_{50} \geq 34 \mathrm{~d}\right)$ and juveniles for $>30 \mathrm{~d}\left(\mathrm{LT}_{50}=14 \mathrm{~d}\right.$ ), indicating that this species is well adapted to living in low oxygen habitats. Unusually, adults under hypoxia had a greater survival rate than control adults in normoxic conditions. Investigation of the salinity tolerance of C. gibba revealed that it could readily survive for $2 \mathrm{~d}$ at 0 to $16 \mathrm{psu}$, with increasing mortality for up to $10 \mathrm{~d}$. In brackish seawater, survival was indistinguishable from that in normal seawater. Examination of the population genetics of 6 different populations of C. gibba separated over various spatial scales, using RAPD PCR methodology, determined that all populations were genetically distinct from each other, including populations separated by as little $5 \mathrm{~km}$, although this may in part be due to the influence of a localised front. This suggests that the larval longevity and dispersal capacity of C. gibba is much less than has been previously considered. In light of all the results, it is concluded that instead of being an insidious pest species, C. gibba is more likely to be an inferior competitor, present in background numbers in normoxic habitats, and only becomes dominant when a system becomes hypoxic, thereby removing competitors and allowing $C$. gibba to flourish in the habitat to which it is adapted.
\end{abstract}

KEY WORDS: Dispersal · Corbula gibba · Hypoxia · RAPD · Respiration · Salinity · Teleplanic

\section{INTRODUCTION}

The bivalve mollusc Corbula gibba (Olivi) is generally regarded as an invasive pest species (Crema et al. 1991, Wilson et al. 1998, Currie \& Parry 1999, Talman \& Keough 2001) colonising organically enriched environments resulting in monospecific stands (Pearson \& Rosenberg 1978, Jensen 1990, Theodorou 1994, Giacobbe \& Rinelli 2002). Accordingly, the accidental introduction of C. gibba into non-indigenous habitats, through ballast water, sea chests etc. (Carlton 1985, Coutts et al. 2003) has led some authors to suggest that $C$. gibba may pose a serious biological threat (Currie \& Parry 1999, Talman \& Keough 2001).
However, given the alleged menace of $C$. gibba, it is surprising that there are only a few, mainly descriptive, studies in the literature about its biology and ecology. In addition, very little is known about its developmental strategy, i.e. length of larval life, and hence there are no estimates of its dispersal potential and/or the speed with which it can colonise new habitats.

In terms of what is known, Corbula gibba is widely distributed from the Norwegian Sea southwards to the west coast of Africa (Tebble 1966). It is commonly found subtidally, in coastal and estuarine silts and muddy gravels. In locations where C. gibba is prevalent, it can account for $>80 \%$ of the total benthic 
biomass, at densities of 1000 to 4500 individuals $\mathrm{m}^{-2}$ (Rosenberg 1977, Jensen 1990, Moodley et al. 1998, Giacobbe \& Rinelli 2002), and is considered to be one of the most productive bivalve species (Laureta 1986, Jensen 1990). C. gibba is both a highly efficient filter feeder, even more so than mussels (Kiørboe \& Mohlenberg 1981) and a surface deposit raker (Yonge 1946). Longevity is around $5 \mathrm{yr}$ (Jensen 1990) and sexes are separate (dioecious), with external fertilisation leading to the production of larvae (Yonge 1946). The length and mode, i.e. planktotrophic or lecithotrophic, of larval life is unknown, although some authors estimate it as greater than 3 mo (i.e. teleplanic) (Jorgensen 1946, Thorson 1946, Jones 1956, Hrsbrenko 1981), whilst others consider it to be less than 1 mo (i.e. actae/anchiplanic) (Yonge 1946, Muus 1973). Thus, the timing of recruitment and frequency (voltism) of spawning appear to be highly variable. It is worth noting, with the exception of Yonge (1946), that all other authors (Jorgensen 1946, Thorson 1946, Jones 1956, Muus 1973, Hrsbrenko 1981) have inferred the larval longevity of C. gibba from the appearance of recruits in the benthos, whereas Yonge (1946) observed that the large yolky eggs of C. gibba were more indicative of a short rather than a long larval life (see also Laureta 1986).

Because of its normal habitat, i.e. muddy hyposaline sediments, Corbula gibba is considered to be resistant to both hypoxia and low salinity conditions. However, the only observation directly pertaining to the hypoxic tolerance of C. gibba is observational in nature, and concluded that adult $C$. gibba could survive hypoxic conditions for $57 \mathrm{~d}$ (Christensen 1970). There are no observations in the literature as to the salinity tolerance of C. gibba.

The aims of this study were: (1) to measure the respiration rate of Corbula gibba to determine its respiratory quotient, i.e. Kleiber's (1961) constant $\beta$, and hence determine (in combination with other data) its functional strategy, i.e. exploitative vs. conservationist (see Holmes et al. 2002 for details); (2) to examine the hypoxic tolerance of C. gibba, adults and juveniles, to determine if this offers an advantage to $C$. gibba under hypoxic conditions; (3) to measure the salinity tolerance of C. gibba; (4) using a RAPD PCR methodology, examine the population genetics of several geographically separated C. gibba populations to assess both its dispersal potential and larval longevity. For this paper, the terms normoxia and hypoxia are used in accordance with Diaz \& Rosenberg (1995) and exploitative and conservationist strategies are as defined by Holmes et al. (2002). For Kleiber's (1961) constant, i.e. the gradient $\beta$ for the regression of log dry flesh weight (i.e. weigth without shell) vs. log respiration, if $\beta$ falls within the range 0.75 to 1 , then the organism is likely to exhibit a conservationist type strategy, i.e. growth, metabolism and/or fecundity are low in order to sustain maintenance costs. In contrast, if $\beta$ falls within the range 1.00 to 1.25 , then the organism is likely to exhibit an exploitative type strategy, i.e. maturation is maximal in the absence of nutritional limits (see Riisgard 1988, Holmes et al. 2002 for full details and West et al. 2002 for discussion).

\section{MATERIALS AND METHODS}

Physiological observations. Collection and maintenance of specimens: All experiments were carried out at Kristineberg Marine Research Station, Fiskebackskil, Sweden, in the autumn of 2000 and 2001. All specimens were collected at the top of Abyfjorden, Sweden $\left(58^{\circ} 28^{\prime} \mathrm{N}, 11^{\circ} 30^{\prime} \mathrm{E}\right)$ using an Agassiz trawl, $1 \mathrm{~mm}$ mesh size. The average population density was $\sim 1800 \pm$ 200 ind. $\mathrm{m}^{2}$ covering a broad size range from 2 to $16 \mathrm{~mm}$ (shell length of the largest valve, 0 to $5+\mathrm{yr}$ ). Once collected, the animals were stored in seawater and transported (within $3 \mathrm{~h}$ of collection) to the marine station, placed into tanks filled with clean sediment, and supplied with fresh running seawater $\left(\sim 10^{\circ} \mathrm{C}\right)$. Examination of the state of the gonads in both years over a wide size range revealed that all but a few were fully spent, suggesting that a spawning event had taken place in September.

Respiration quotient: Oxygen consumption was measured individually for 26 randomly selected animals covering a size range of 7 to $12 \mathrm{~mm}$ (shell length of the largest valve) at $10^{\circ} \mathrm{C}$ using oxygen electrodes in closed system, $50 \mathrm{ml}$ (total volume) respirometers (Model No: OXY046A, Rank Brothers). Respiration was only measured within the normoxic range of oxygen concentration, i.e. $>2 \mathrm{ml} \mathrm{O}_{2} \mathrm{l}^{-1}$, over a period of $4 \mathrm{~h}$, at $10 \mathrm{~min}$ intervals, replicated 3 times for each individual. At the end of the experiment, the organisms were dried and their dry flesh and whole dry weight recorded.

Hypoxic tolerance: Measurement of the hypoxic tolerance of adult and juvenile (i.e. $<2.0 \mathrm{~mm}$ shell width) Corbula gibba was in an identical manner to that outlined by Holmes et al. (2002), with the exception that water controls were taken every $4 \mathrm{~d}$ in the first instance, and every $8 \mathrm{~d}$ in the second instance. Since after $\sim 12 \mathrm{~d}$ the control death rate (due to starvation) was indistinguishable from the treatment death rate (due to starvation and hypoxia) in the first series of experiments, a second series of experiments were run, whereby a $\sim 10 \mathrm{mg}$ portion (dry weight) of Algarde vacation food block (Algarde Aquatic Products) was added to each container at the start of the experiment. The vacation food block consists of freeze dried 
algae embedded in plaster-of-paris, which dissolves slowly over time releasing the algae gradually. The vacation food block portions were microwaved, to ensure sterility, and pre-soaked in autoclaved filtered $(0.2 \mu \mathrm{m})$ seawater (AFS) to eliminate trapped air.

Salinity tolerance: The salinity tolerance of Corbula gibba was examinated as follows: (1) a series of 5 dilutions of AFS at $100 \%(32.70)$, $75 \%(24.52), 50 \%$ (16.35), $25 \%$ (8.17) and $0 \%(0)$ psu were made using distilled water. The salinity at the collection site ranged between 30 and 34, depending on the amount of freshwater runoff; (2) 100 bottles of $15 \mathrm{ml}$ nominal capacity were filled with the water for each dilution (salinity), i.e. $\mathrm{n}=500$ in total; (3) 3 randomly selected adult $C$. gibba were then placed into each pre-filled $15 \mathrm{ml}$ bottle. All bottles were left under a $12 \mathrm{~h}$ day/ night cycle and maintained at $10^{\circ} \mathrm{C}$ for the duration of the experiment. Each day, all bottles were visually checked to determine whether the animals were alive or dead. Dead individuals were removed from the

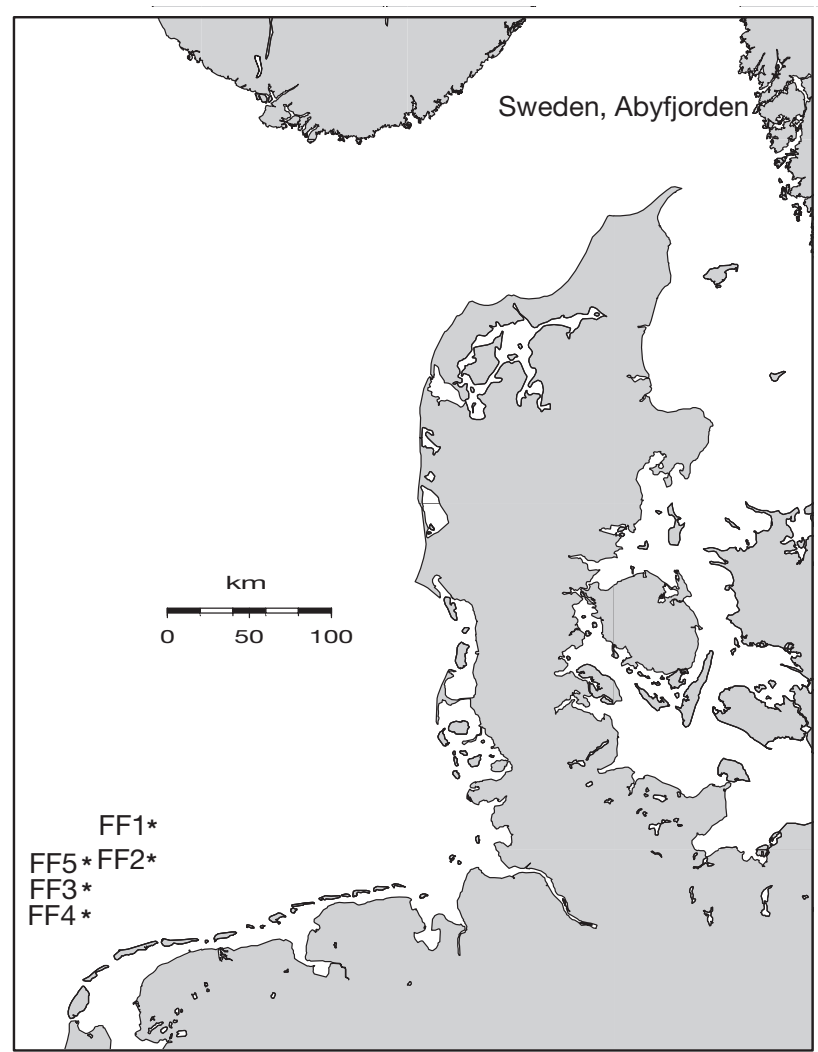

Fig. 1. Locations of populations sampled (descriptions and site codes in Table 1) bottles and their deaths recorded. If the relevant bottles contained other bivalves, the water was changed and the bottles returned to the experiment. The experiment was ended after $10 \mathrm{~d}$.

Population genetics. Adult Corbula gibba (30 individuals per population) covering a range of sizes were dredged from 5 different sites in the North Sea and 1 site (outgroup) in Sweden in 2001 (Table 1, Fig. 1). Selection of the populations (sites) was based on both the presence of C. gibba and their relative position/distance in regard to to other populations, such that the Frisian Front populations FF3, FF4 and FF5 were relatively close to each other ( 5 to $13 \mathrm{~km}$ ) but at an intermediate distance $(33 \mathrm{~km})$ from the FF1 and FF2 populations (20 km separation) which, in turn, were close $(20 \mathrm{~km})$ to each other but far $(625 \mathrm{~km})$ from the Swedish outgroup population. Once collected, all specimens were immediately frozen $\left(-80^{\circ} \mathrm{C}\right)$ and stored at $-20^{\circ} \mathrm{C}$ for future processing.

Total DNA extractions, RAPD PCR protocol and fragment identification: DNA extraction, the RAPD protocol adopted and fragment identification were identical to those outlined by Holmes et al. (2004), with the exception that the 5 different 10 base-pair (bp) primers were selected along with their individually optimised 2nd step cycle number are given in Table 2 . Mixed sample batches (i.e. individuals from several populations) were run together in each PCR reaction.

Table 2. Primers selected and number of cycles in second step of amplification procedure. \%GC: \% guanine/cytosine; Opt. no.: optimal number of second-step cycles; No. polymorph: no. of polymorphic bands

\begin{tabular}{|llcccc|}
\hline Primer & Sequence (5'-3') & $\begin{array}{c}\% \\
\text { GC }\end{array}$ & $\begin{array}{c}\text { Opt. } \\
\text { no. }\end{array}$ & $\begin{array}{c}\text { Total } \\
\text { bands }\end{array}$ & $\begin{array}{c}\text { No. poly- } \\
\text { morph }\end{array}$ \\
\hline OPC04 & CCGCATCTAC & 60 & 35 & 23 & 22 \\
OPG07 & GAAVVTGCGG & 70 & 35 & 26 & 26 \\
OPM18 & CACCATCCCT & 60 & 29 & 16 & 14 \\
UBC212 & GCTGCGTGAC & 70 & 29 & 25 & 24 \\
UBC167 & CCAATTCACG & 50 & 35 & 20 & 20 \\
\hline
\end{tabular}


Random retrials were performed for each primer to ensure reproducibility between both PCR reaction conditions and gel resolution with a randomly selected series of samples from all populations $(n=26)$. If the results on a gel appeared to be erroneous, i.e. in comparison to existing samples, then a fresh gel was run and a repeat PCR amplification made for those samples.

RADP data analysis: Initially, a matrix of Euclidean (squared) distances was calculated from the RAPD data $(\mathrm{n}=180)$. The resulting matrix was subjected to principal coordinates analysis (PCO) using MVSP (version 3.13d, Kovach Computing Services), and the resulting factors plotted. A discriminant analysis was performed on the resultant factors, to assess the reliability with which individuals could be ascribed to their respective populations. To test the population structure derived from the PCO analyses, the data was then examined with AMOVA (analysis of molecular variance) using the ARLEQUIN package (Version 2; Schneider et al. 2000). One thousand random permutations of the data matrix were carried out to assess the significance of the variance components and of the pairwise variances for each population.

A neighbour joining (NJ) analysis was then performed on the data from a distance matrix derived using Parsimony, PAUP* (Swofford 2002), and the robustness of the resulting tree tested by bootstrapping the data, by resampling each individual 1000 times. Finally, a series of Mantel tests were performed to examine the correlation, if any, between the geographical distances between the populations and $\Phi_{\mathrm{ST}}$, Slatkin's (1985) linearised $F_{\mathrm{ST}}$ and the distances derived from the NJ analysis.

\section{RESULTS}

\section{Respiration, metabolism and production}

Linear regression of the mean amount of oxygen consumed by each bivalve (i.e. $\mathrm{n}=26$ ) against whole dry weight and dry flesh weight (DFW) revealed a positive relationship for both variables (Fig. 2). The mean \pm standard error (SE) respiration rate of an average sized Corbula gibba $(0.084 \pm 0.003 \mathrm{~g} \mathrm{DFW})$ was $3.12 \pm$ $0.05 \mu \mathrm{O} \mathrm{O}_{2} \mathrm{~h}^{-1}\left(0.063 \pm 0.001 \mathrm{~J} \mathrm{~h}^{-1}\right)$. The calculated respiratory quotient $(\beta)$ (i.e. for the dry flesh weight) was $0.61 \pm 0.16$, falling within the range 0.75 to $1(p=0.03$, calculated using $t$-tests).

\section{Hypoxic tolerance}

The initial oxygen concentration (mean $\pm \mathrm{SE}$ ) of the seawater at the start of both experiments was $\leq 1.61 \pm$ $0.23 \mathrm{ml} \mathrm{O}_{2} \mathrm{l}^{-1}$; that is, the seawater can be regarded as

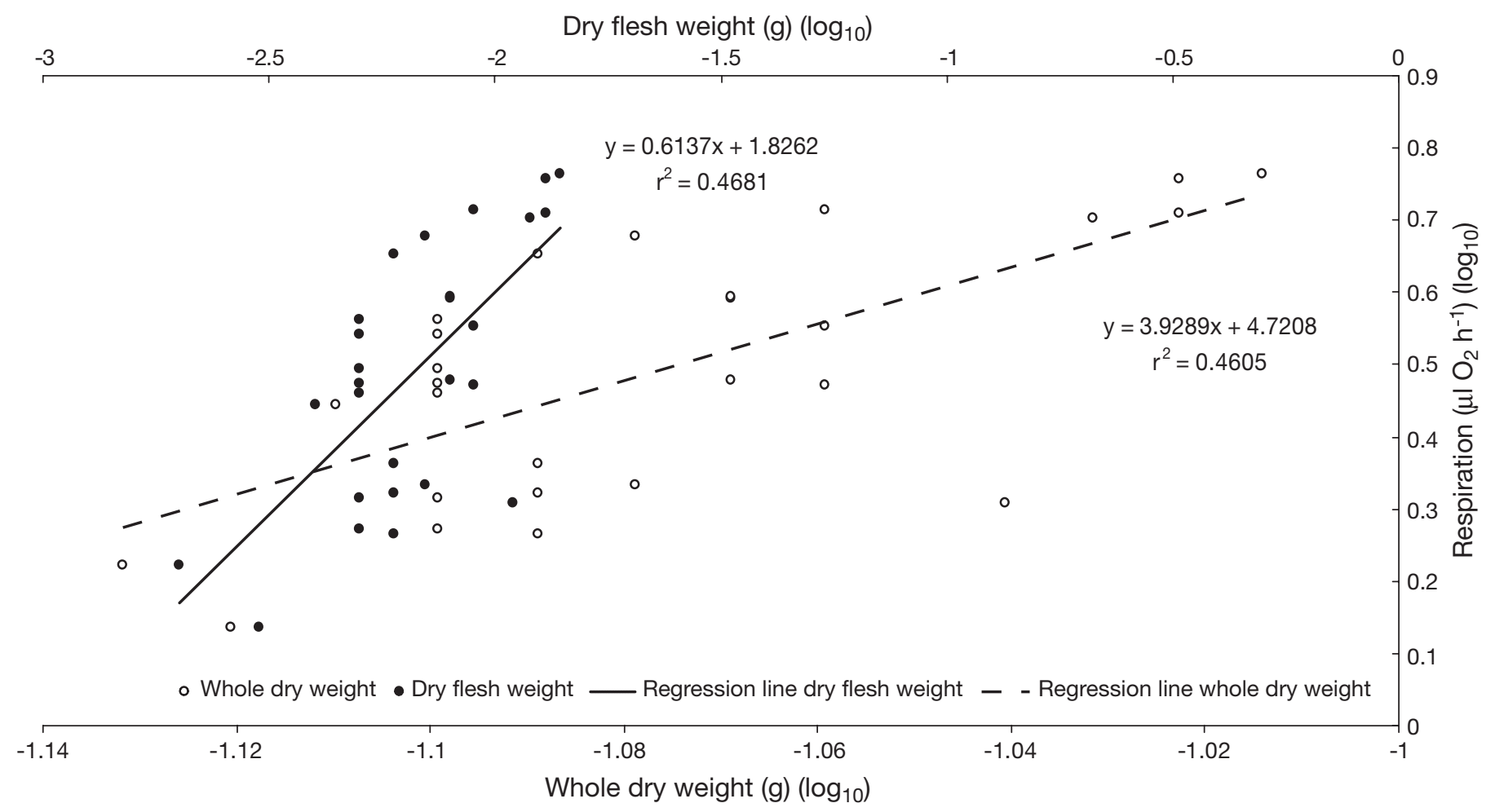

Fig. 2. Linear regression of respiration data for Corbula gibba 




Fig. 3. Mortality of fed Corbula gibba juveniles (2nd experiment) under hypoxia

being hypoxic at the start of the experiments (Diaz \& Rosenberg 1995). Comparison of the oxygen concentrations of the water controls during the experiments, using a one-way analysis of variance, revealed that the oxygen concentration of the control water did not change over the duration of any experiment (Fig. 3). (In Fig. 3, only data for the second series of experiments are presented, for brevity).

For the first series of experiments, analysis of the survival data for Corbula gibba over time, using the Kaplan-Meier procedure with log rank comparison and accounting for censored observations revealed (1) that the survival rate of the adult treatment animals, over the whole experiment, was different to that of the juvenile treatment and adult and juvenile control animals ( $p$ > 0.001) (Fig. 4); (2) that there was no difference between the survival rate of the juvenile treatment, juvenile control and treatment control animals ( $p=0.284)$; (3) that for the adult treatment animals the mean $\pm \mathrm{SE}$ survival time was $25.40 \pm 0.85 \mathrm{~d}$ (median $=$ $>34 \mathrm{~d}, \mathrm{LT}_{50} \cong>34 \mathrm{~d}$ ) whilst the mean survival time for the adult control animals was $21.86 \pm 0.88 \mathrm{~d}$ (median $=$ $22 \mathrm{~d}, \mathrm{LT}_{50} \cong 22 \mathrm{~d}$ ) (Fig. 4); (4) that for the juvenile treatment animals the mean \pm SE survival time was $16.98 \pm$ $0.79 \mathrm{~d}$ (median $=14 \mathrm{~d}, \mathrm{LT}_{50} \cong 14 \mathrm{~d}$ ) whilst the mean survival time for the juvenile control animals was $19.73 \pm$ $1.39 \mathrm{~d}$ (median $=19 \mathrm{~d}, \mathrm{LT}_{50} \cong 20 \mathrm{~d}$ ) (Fig. 4).
An alternative analysis of the adult data, however, using a Cox regression model derived from the weighted residuals, revealed that survival of adult Corbula gibba differed between treatment and control conditions during the early part of the experiment $\left(\chi^{2}=9.85, \mathrm{p} \leq 0.01\right)$; i.e. (1) until approximately Day 8, there was a difference between survival rates of treatment and control adults, with the treatment adults dying more often than controls (Fig. 4); (2) after Day 8, mortality of the control adults rapidly increased until, by Day 10, it had reached a rate approximately equal to that of the treatment adults, with both rates thereafter remaining proportionately equal.

In effect, mortality of the treatment adults due to hypoxia was distinguishable from mortality due to starvation up to Day 8. Thereafter, mortality from hypoxia was indistinguishable from and equal to that from starvation. For the first series of experiments using juveniles, control survival was indistinguishable from treatment survival for the entire duration of the experiment. This suggests that, for this experiment, starvation was more important than hypoxia in determining the ability of Corbula gibba to survive. In both the adult treatment and control samples $\sim 90 \%$ of the bivalves had died by the end of the experiment (30 d), and in the juvenile treatment and control samples $\sim 60 \%$ had died by the end of the experiment (14 d). 

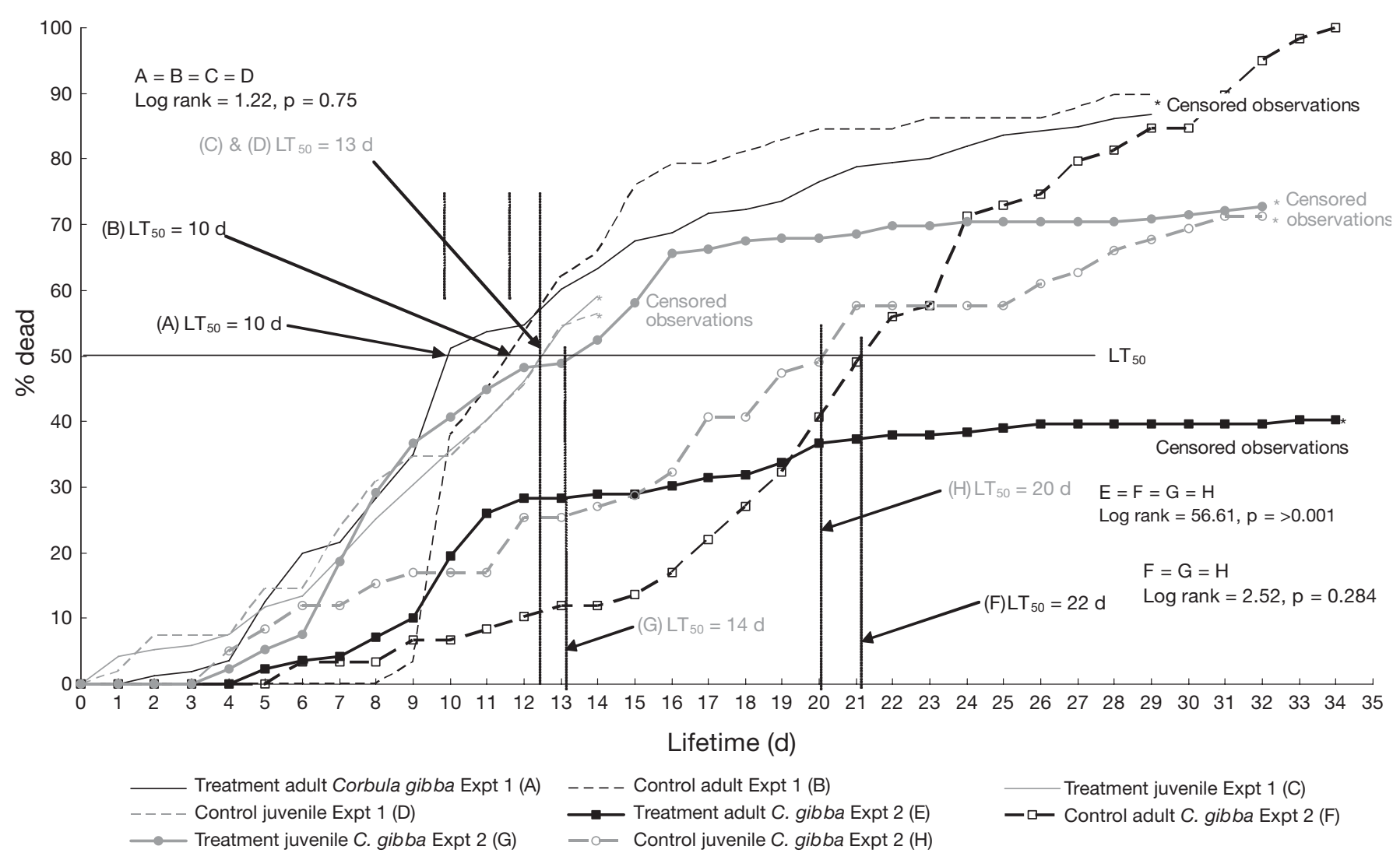

Fig. 4. Cumulative percent mortality during hypoxia experiments

For the second series of experiments, analysis of the survival data of Corbula gibba over time, using the Kaplan-Meier procedure with log rank comparison and accounting for censored observations, revealed that (1) the survival rate of the treatment adults over the whole experiment differed from that of the treatment juveniles and adult and juvenile controls ( $p>0.001$ ); (2) there was no difference between the survival rate of the treatment juveniles, control juveniles and control adults $(\mathrm{p}=0.284) ;(3)$ the mean \pm SE survival time was $25.40 \pm 0.85 \mathrm{~d}$ (median $=>34 \mathrm{~d}, \mathrm{LT}_{50} \sim>34 \mathrm{~d}$ ) for treatment adults and $21.86 \pm 0.88 \mathrm{~d}$ (median $=22 \mathrm{~d}$, $\mathrm{LT}_{50} \sim 22 \mathrm{~d}$ ) for control adults; (4) the mean $\pm \mathrm{SE}$ survival time was $16.98 \pm 0.79 \mathrm{~d}$ (median $=14 \mathrm{~d}, \mathrm{LT}_{50} \sim$ $14 \mathrm{~d}$ ) for treatment juveniles and $19.73 \pm 1.39 \mathrm{~d}$ (median $=$ 19 d, $\mathrm{LT}_{50} \sim 20 \mathrm{~d}$ ) for control juveniles (Fig. 4).

It would appear that under hypoxic conditions, adult Corbula gibba can survive better than juvenile $C$. gibba and adult C. gibba under normoxic and low quality conditions.

An alternative analysis of the juvenile data, using a Cox regression model, derived from the weighted residuals, revealed that survival of juvenile Corbula gibba between treatment and control conditions differed for the duration of the experiment $\left(\chi^{2}=11.31\right.$, p 0.01), i.e. (1) until approximately Day 6, there was no difference between survival rates of treatment and control juveniles (Fig. 4); (2) after Day 6, the death of treatment juveniles increased, such that by Day 7 it exceeded that of the controls, with both rates thereafter remaining relatively proportionate to each other until approximately Day 29, when they converged (Fig. 4).

In effect, in the second juvenile experiment, the increase in mortality of juvenile Corbula gibba from hypoxia, was evident from Day 6 of the experiment. By Day 29, mortality rates due to hypoxia and starvation (i.e. poor quality conditions) were effectively equal.

Correlation, using Spearman's rho $\left(\mathrm{R}_{\mathrm{SC}}\right)$, of the shell length, height, width and whole body dry weight data to the survival data, failed to produce any statistically significant correlation for any experiment, i.e. death due to hypoxia did not appear (in these experiments) to be related to body size. Correlation analysis, using Spearman's rho of the lifetime of Corbula gibba vs. the mean oxygen concentration of the treatment water samples at the time of death for that day, produced a negative correlation for all experiments, i.e. the $\mathrm{O}_{2}$ concentration in the water containing the treatment animals dropped over time, as they respired, leading to their eventual death (Fig. 3). Correlation of the number of animals dying per day against the mean $\mathrm{O}_{2}$ concentration of the animals that died on that day (using 


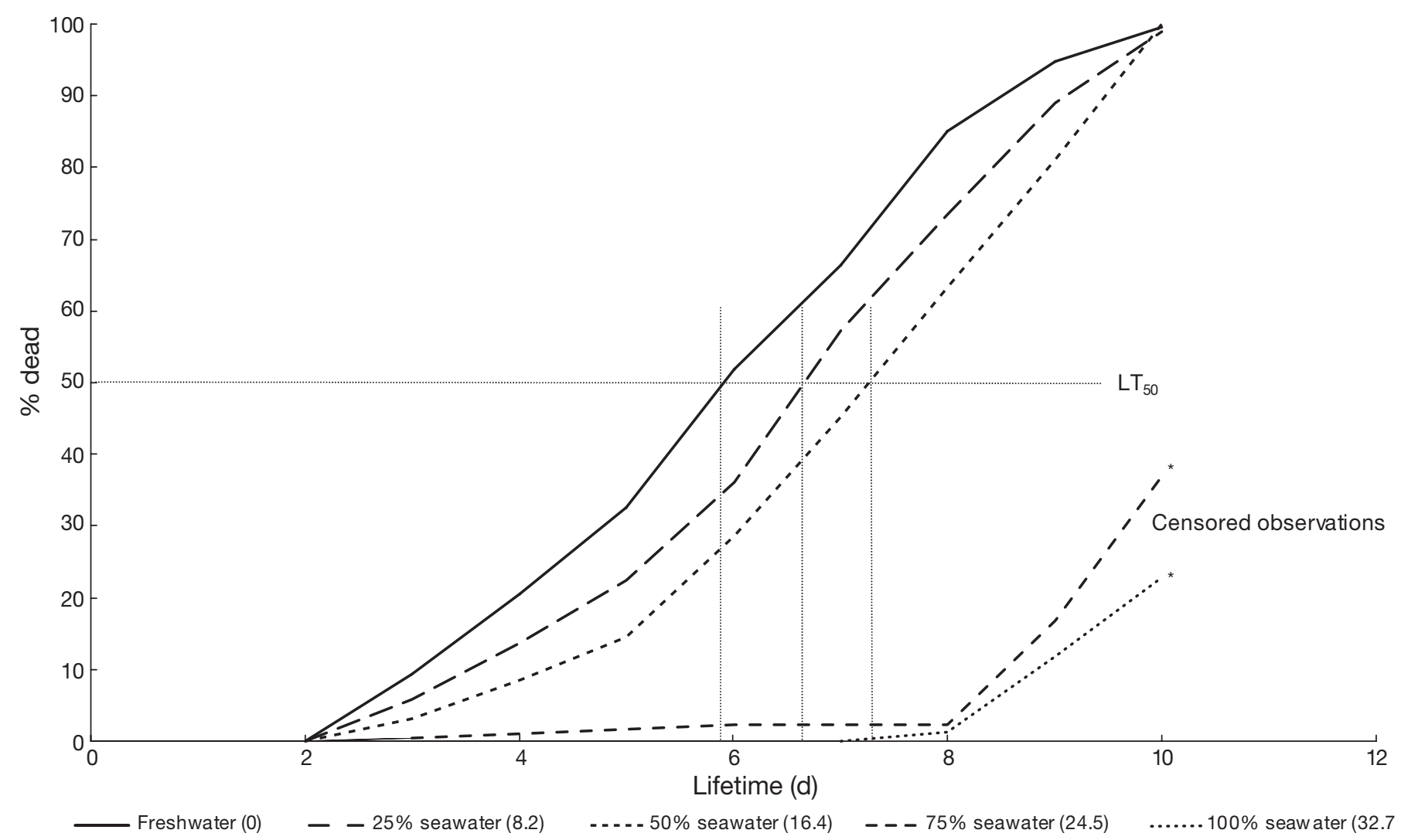

Fig. 5. Cumulative percent mortality of Corbula gibba as a function of salinity. Numbers in brackets represent practical salinity units (psu)

Spearman's rho to determine if there was a threshold $\mathrm{O}_{2}$ concentration lower than that at the start of the experiment that caused death) produced no statistically significant correlation, i.e. the initial $\mathrm{O}_{2}$ concentration of the water was sufficient to cause death due to hypoxia (Fig. 3).

\section{Salinity tolerance}

Analysis of the survival data for Corbula gibba over time, using the Kaplan-Meier procedure with log rank comparisons and assuming that each individual is an independent observation, revealed that the survival rates of the animals differed as a function of salinity, ( $p \leq 0.001$ ) (Fig. 5) as follows: (1) the mean \pm SE survival time at $0 \mathrm{psu}(0 \%$ seawater $)=6.46 \pm 0.16 \mathrm{~d}$ (maximum survival time $=10 \mathrm{~d}_{i}$ median $=6 \mathrm{~d}_{i} \mathrm{LT}_{50}=$ $6 \mathrm{~d}$ ); (2) for the $8.17 \mathrm{psu}$ (25\% seawater) treatment, the mean $\pm \mathrm{SE}$ survival time was $7.10 \pm 0.16 \mathrm{~d}$ (maximum survival time of $10 \mathrm{~d}$; median $=7 \mathrm{~d}_{i} \mathrm{LT}_{50}=7 \mathrm{~d}$ ); (3) for the $16.35 \mathrm{psu}$ ( $50 \%$ seawater) treatment the mean $\pm \mathrm{SE}$ survuval time was $7.60 \pm 0.14 \mathrm{~d}$ (maximum survival time of $10 \mathrm{~d}_{i}$ median $=8 \mathrm{~d}_{i} \operatorname{LT}_{50}=8 \mathrm{~d}$ ); (4) for the $24.52 \mathrm{psu}(75 \%$ seawater) treatment, the mean $\pm \mathrm{SE}$ survival time was $9.77 \pm 0.07 \mathrm{~d}$ with a maximum sur- vival time of $>10 \mathrm{~d}$ (median $>10 ; \mathrm{LT}_{50}>10 \mathrm{~d}_{i}(5)$ for the $32.70 \mathrm{psu}(100 \%$ seawater) treatment, the mean $\pm \mathrm{SE}$ survival time was $9.89 \pm 0.04$ d (maximum survival time of $>10 d_{i}$ median $>10 ; L_{50}>10$ ). Although there is a statistically significant difference between mean survival in the 100 and $75 \%$ seawater treatments, this difference is effectively negligible (Fig. 5).

In summary, in water from 0 to $16.35 \mathrm{psu}$, Corbula gibba can survive for up to $2 \mathrm{~d}$ without mortality and up to $10 \mathrm{~d}$ with increasing mortality. Survival of $C$. gibba in brackish seawater (i.e. the $75 \%$ seawater treatment) is little different from that in normal seawater.

\section{Population genetics (RAPD analysis)}

From the 180 individuals of the 6 populations studied, the 5 primers used, amplified a total of 106 different polymorphic fragments (Table 2). A complete data set of the banding patterns for all populations and primers can be obtained at www.sebby.co.uk/data. htm. Analysis of the data using principal coordinates analysis (PCO) extracted 4 factors, accounting for 29, 19,16 and $9 \%$ of the total variance, respectively. A plot of these factors revealed that all populations appeared 
to be different from each other. In line with the PCO results, discriminant analysis revealed that individuals could be assigned to their source population on the basis of their banding patterns (molecular phenotype) with 100\% accuracy.

Analysis of molecular variance based on the precept (arising from the PCA analysis) that all populations were different from each other, revealed that $\sim 55 \%$ of the total variance could be attributed to between-population differences and the remaining $~ 45 \%$ to withinpopulation differences (Table 3). Any attempts at subdividing the populations into groups, e.g. combining the Frisian Front populations, resulted in a decrease in the between-population variance and a corresponding increase in the within-population variance. In effect, the majority of the variance between samples arises from between-population rather than the withinpopulation differences. Calculation of the pairwise between-population variances $\left(\Phi_{\mathrm{ST}}\right)$, after correction for multiple comparisons, revealed that the genetic identity (determined by the RAPD banding patterns) of all
Table 4. Pairwise population variance, $\Phi_{\mathrm{ST}}\left(F_{\mathrm{ST}}\right)$ (all significant at $\mathrm{p} \leq 0.01)$. Site codes as in Table 1

\begin{tabular}{|lccccc|}
\hline & FF1 & FF2 & FF3 & FF4 & FF5 \\
\hline FF2 & 0.57 & & & & \\
FF3 & 0.47 & 0.56 & & & \\
FF4 & 0.62 & 0.69 & 0.48 & & \\
FF5 & 0.54 & 0.59 & 0.47 & 0.54 & \\
Sweden & 0.54 & 0.62 & 0.49 & 0.55 & 0.45 \\
\hline
\end{tabular}

populations differed from each other (Table 4). In addition, both the among-population (Table 3) and betweenpopulation (Table 4) $\Phi_{\mathrm{ST}}$ values were high, indicating a considerable degree of genetic structuring.

Construction of a neighbour joining tree revealed, as did the discriminant analysis, that the individuals from

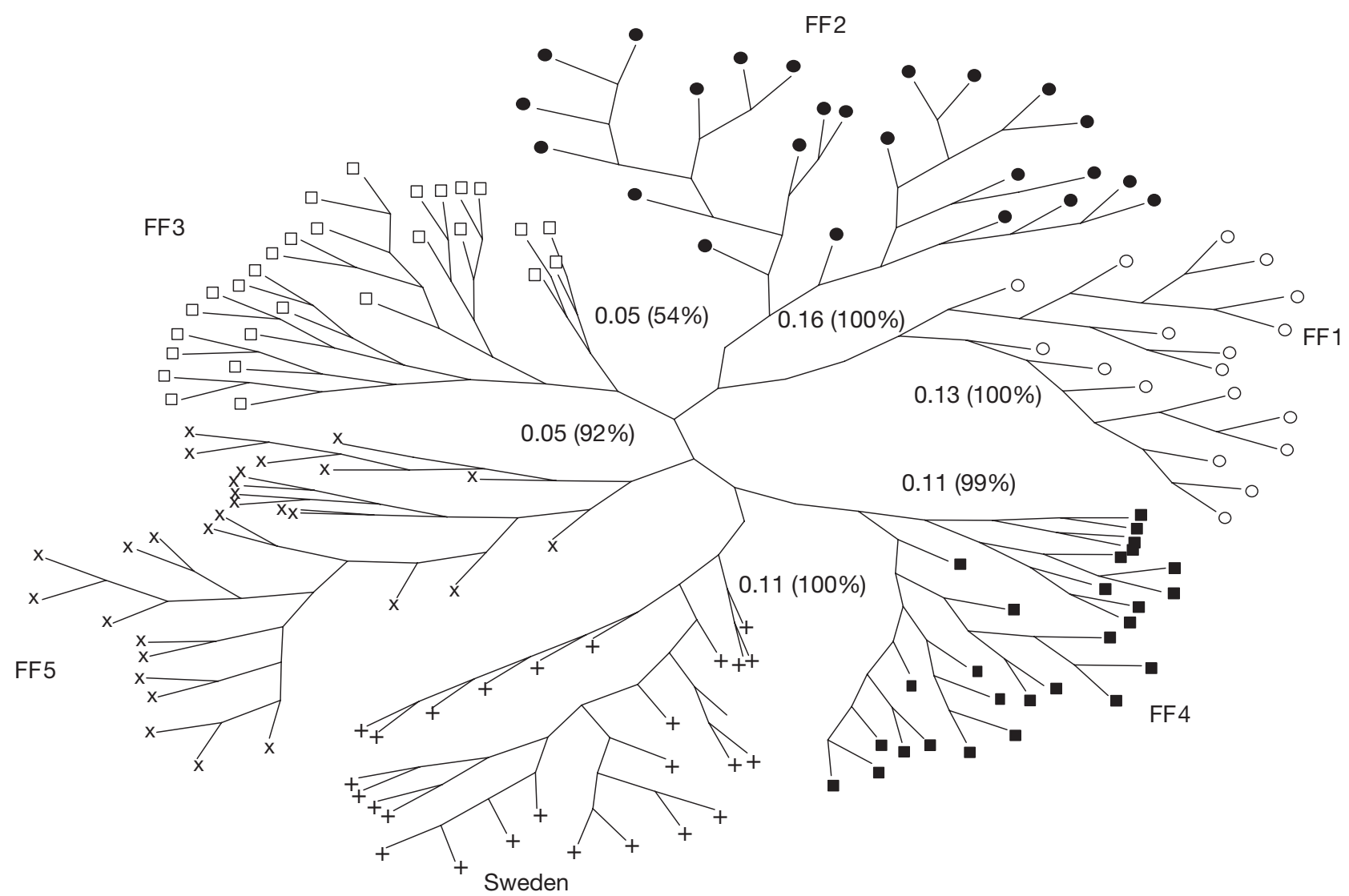

Fig. 6. Unrooted dendrogram calculated from RAPD penotypes using neighbour-joining analysis. Numbers along main branches: branch length (from center); numbers in brackets: bootstrap values (\% accuracy calculated from 1000 replicates) for relevant branches. Site codes as in Table 1 


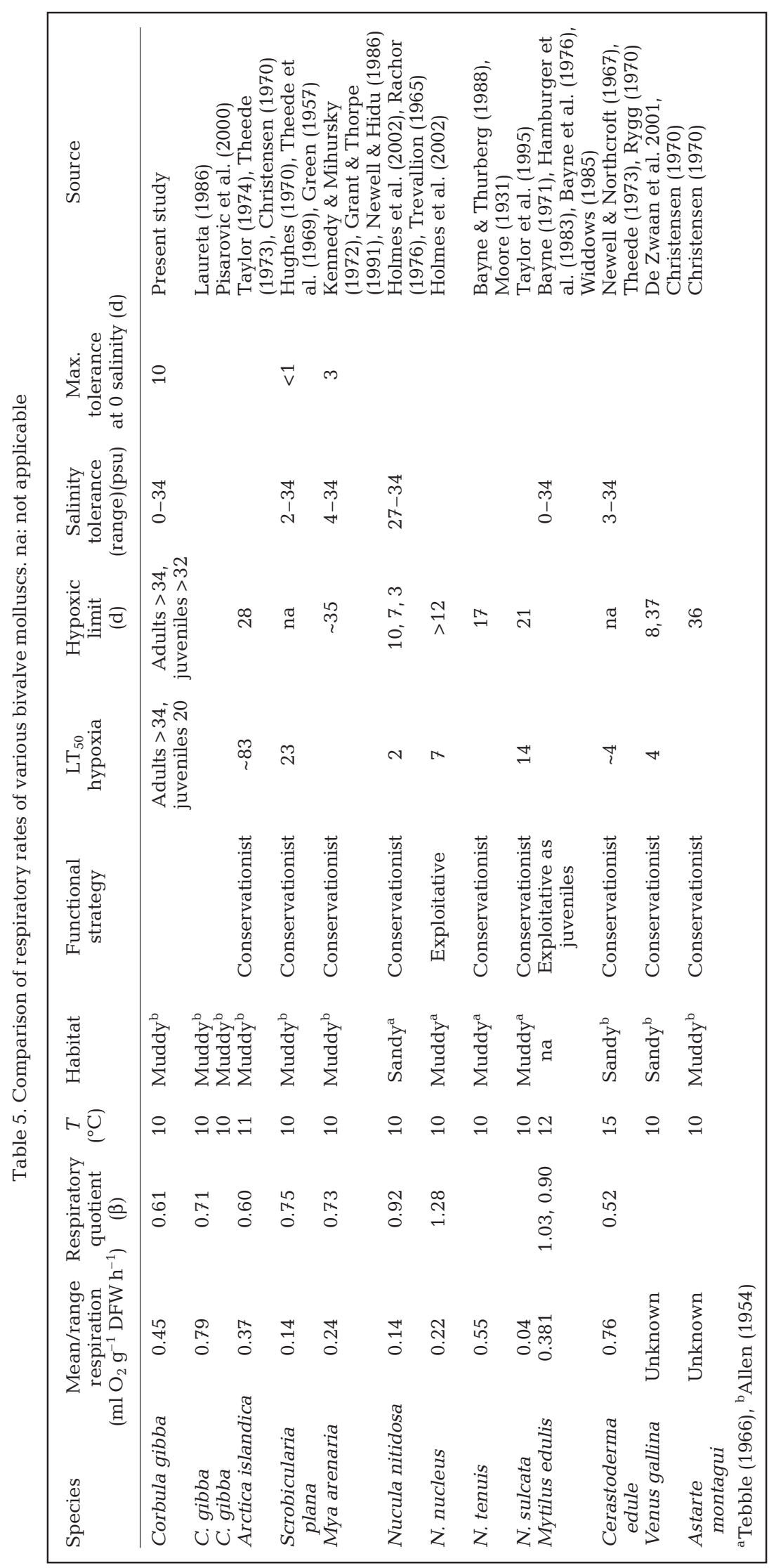

all populations could be separated into the respective populations on the basis of their banding patterns (Fig. 6). Bootstrapping, based on resampling each individual, of the derived tree revealed (although with less accuracy than the discriminant analysis) that the assignment of a particular individual to a particular population could be made for the majority of the populations with $\geq 92 \%$ accuracy (100\% accuracy for the FF1 and FF2 populations, 99\% accuracy for the FF4 population, $92 \%$ for the FF5 population and $54 \%$ for the FF3 population) (Fig. 6).

Mantel tests performed to examine the correlation, if any, between genetic and geographical distances/differences between the populations using $\Phi_{\mathrm{ST} \text {, }}$ Slatkin's (1985) linearised $F_{\mathrm{ST}}$ and the results derived from the neighbour-joining analysis, revealed that there appeared to be no relationship between geographical and genetic distance for any metric used.

\section{DISCUSSION}

Measurement of the respiration of Corbula gibba revealed that an average sized individual ( 9 mg dry flesh weight) had a respiratory demand of $\sim 75.0 \mu \mathrm{O}_{2}$ $24 \mathrm{~h}^{-1}\left(1.50 \mathrm{~J}_{\text {ind. }}{ }^{-1} 24 \mathrm{~h}^{-1}\right)$, which is of the same order as that recorded by Laureta (1986) and by Pisarovic et al. (2000) (Table 5). In terms of secondary production, for the population sampled at Abyfjorden this equates to $457 \mathrm{~kJ} \mathrm{~m}^{-2}$ $\mathrm{yr}^{-1}$ (see Holmes et al. [2002] for calculation details and Laureta [1986], Jensen [1990] for comparisons). Calculation of the respiratory quotient (Kleiber's constant $\beta$ ) for $C$. gibba produced a value of 0.61 , in line with the value calculated by Laureta (1986) using a different methodology (Table 5). Hence in terms of its metabolism, it is concluded that C. gibba adopts a conservationist type strategy, i.e. $\beta$ falls within the range of 0.75 to 1 (see Riisgard 1998, Holmes et al. 2002). It should be noted that because the measurements were made at roughly the same time over $2 \mathrm{yr}$, there may be seasonal variation in the respiratory quotient of $C$. gibba, which has not been 
accounted for (see Heilmayer et al. 2004 for example). Comparison of the respiration rate and quotient obtained for C. gibba with those of other conservationist type species revealed little difference (Table 5).

Examination of the hypoxic tolerance of Corbula gibba determined that both adults and juveniles could survive for more than $32 \mathrm{~d}$. Even after $34 \mathrm{~d}$, adult $C$. gibba supplied with food had not attained $50 \%$ mortality $\left(\mathrm{LT}_{50}\right)$. Compared to the hypoxic tolerance recorded for other species, C. gibba would appear to be one of the most resistant species (Table 5). The only recorded exceptions are data of Theede et al. (1969) for Arctica islandica and Mytilus edulis; however, their results may differ because of their different and possibly less stringent methodologies. In terms of resistance to starvation/poor quality conditions the first hypoxic experiment revealed that adult $C$. gibba could survive for $>30 \mathrm{~d}$ without food with an $\mathrm{LT}_{50}$ of 12 to $13 \mathrm{~d}$ for the adult and juvenile control specimens. In the second hypoxic experiment, juvenile C. gibba were less tolerant than the adults with the juveniles surviving for $>31 \mathrm{~d}$ with $\mathrm{a} \mathrm{LT}_{50}$ of $14 \mathrm{~d}$.

Surprisingly, the treatment adult Corbula gibba had a much greater survival rate than the corresponding controls, with all control individuals having died by the end of the experiment compared to $<50 \%$ of the treatment individuals. It is likely that under hypoxic conditions C. gibba reduces its metabolic rate and hence its maintenance costs, resulting in increased tolerance (McMahon \& Wilson 1981). Alternatively, the build up of anaerobic metabolites may provide some form of enhanced resistance (Abele-Oeschger \& Oeschger 1995). The greater susceptibility of juveniles to hypoxia, combined with the increased success of adults, may explain both the patchy and fixed size class stands recorded by some authors (see Muus 1973, Hrsbrenko 1981, Jensen 1990, Rueda et al. 2001 for details). It is worth noting, given the supposedly pernicious nature of C. gibba, that samples taken by boxcores in Abyfjorden consisted of a wide range of fauna including Arctica islandica, Nucula nitidosa, Abra prismatica, A. nitida and Mysia undata along with a variety of other organisms, with $A$. islandica making up $>50 \%$ of the total biomass of the cores $(n=5)$.

Examination of the salinity tolerance of Corbula gibba revealed that individuals could readily survive for $10 \mathrm{~d}$ at $\sim 24$ psu. Below 24 psu, mortality rapidly increased with decreasing salinity, with a maximal survival time of $\sim 10 \mathrm{~d}$ in freshwater $\left(\mathrm{LT}_{50}=6 \mathrm{~d}\right)$. In comparison with the salinity tolerance of other bivalve species (Table 5), C. gibba appears to be extremely well adapted to living in hyposaline conditions, reflective of its lotic and lentic cousins. The salinity tolerance of C. gibba suggests, as does its hypoxic tolerance, that it is adapted to occupying highly stressful (marginal) habitats. In general, species that successfully occupy highly stressful environments, although dominant within their own ecosystem are inferior competitors occupying what is effectively a suboptimal habitat with reduced or absent competitive pressures. The benefit of reduced competition is weighed against the cost of high maintenance/adaptive costs associated with living in such an environment. For C. gibba, this is borne out by the fact that populations are frequently found in unstable, perturbed and/or denuded habitats (Crema et al. 1991, Theodorou 1994, Currie \& Parry 1999, Pruvot et al. 2000, Giacobbe \& Rinelli 2002 for examples). Its success (Wilson et al. 1998, Currie \& Parry 1999, Talman \& Keough 2001) in occupying less stressful habitats in locations outside its normal distribution (e.g. in Australia) can be explained by the absence in such locations of its usual competitors. It is worth noting that during a 30+ yr bi-annual survey data (Dekker \& Beukema 1993) C. gibba was never found in the Western Wadden Sea, although suitable habitats exist there and there is an extant population some $30 \mathrm{~km}$ northwards in the North Sea (the FF4 population).

Examination of the population genetics of Corbula gibba revealed that populations separated by as little as $5 \mathrm{~km}$ were genetically distinct from each other. Similarly, there was no correlation between genetic and geographical distance irrespective of the metric used. Similar levels of genetic differentiation, using the same methodology, have been recorded for the actaeplanic bivalve Arctica islandica (Holmes et al. 2003) and the aplanic bivalve Abra tenuis (Holmes et al. 2004).

The lack of any genetic similarity between the different populations is surprising, especially over such short spatial scales, if we consider that Corbula gibba is teleplanic as suggested by Jorgensen (1946), Thorson (1946), Jones (1956) and Hrsbrenko (1981). Under a panmictic hypothesis (i.e. mode of reproduction/development is correlated with dispersal capacity), our results would suggest that C. gibba adopts an anchi/ aplanic strategy. However, similar results have been recorded for both actaeplanic and teleplanic species in both population genetic (Burton \& Fieldman 1982, Heipel et al. 1998) and other (Moore 1977, Johannesson 1988) studies. For example, Bhaud (1998) showed that there is no relationship between the mode of reproduction/developmental strategy adopted by polychaetes and their dispersal potential, with some direct developers having a more widespread dispersal than closely related teleplanic species. Such species may produce along-lived larval life stage not to ensure dispersal (dispersal can occur alternatively in the juvenile or adult phase, see Highsmith 1985, Olivier et al. 1996 for examples), but rather to reduce conspecific predation and/or to avoid competition with the parental generation etc. (see Pechenik 1999 for discussion). Irrespective of these 
considerations, it is probable, given Yonge's (1946) observations and the population genetic data recorded herein, that C. gibba adopts an anchi/actaeplanic rather than teleplanic distribution mode. However, in the absence of any direct observations on its reproduction, there is no way to substantiate this proposal.

In terms of the observed genetic structure, it is probable that the populations derive from a few individuals, with considerable inbreeding and self recruitment (the pairwise population $\Phi_{\mathrm{ST}}$ 's were reasonably high: Table 4). There is some evidence for the Frisian Front populations at least, that the prevailing water currents may constrain and concentrate existing populations/larval dispersal (see Creutzberg 1986). However, without further studies this remains speculation.

In summary, Corbula gibba appears to have a considerable hypoxic and salinity tolerance combined with a conservationist metabolic strategy, suggesting that, rather than being an invasive weed, it is in fact an inferior competitor that occupies very specific habitats to which it is adapted, hence its high maintenance costs and low respiratory quotient ( $\beta$ ). Correspondingly, the population genetic data demonstrate that, irrespective of its reproduction/developmental strategy, C. gibba has a very restricted dispersal capacity contrary to what would be required if it were an invasive species. The only possible negative biological effect of C. gibba on other species may derive from its sheer abundance. However, such events are likely to be limited to the duration of the perturbation which has resulted in the change of the local environmental conditions and/or the decline of more competitive species.

Acknowledgements. We note that this research was, in part, funded by a NIOZ fellowship held by S.P.H., and that the collection of specimens in Sweden was made possible by the European Union Access to Research Infrastructure (ARI) Scheme (grant no: ARI P.2).

\section{LITERATURE CITED}

Abele-Oeschger D, Oeschger R (1995) Hypoxia-induced autoxidation of hemoglobin in the benthic invertebrates Arenicola marina (Polychaeta) and Astarte borealis (Bivalvia) and the possible effects of sulfide. J Exp Mar Biol Ecol 187:63-80

Allen JA (1954) A comparative study of the British species of Nucula and Nuculana. J Mar Biol Assoc UK 33:457-472

Bayne BL (1971) Oxygen consumption by 3 species of Lamellibranch mollusc in declining ambient oxygen tension. Comp Biochem Physiol 40:955-958

Bayne BL, Thurberg FP (1988) Physiological measurements on Nucula tenuis and on isolated gills of Mytilus edulis and Carcinus maenas. Mar Ecol Prog Ser 46:129-134

Bayne BL, Bayne CJ, Carefoot TC, Thompson RJ (1976) Physiological ecology of Mytilus californianus Conrad: adaptations to low oxygen tension and air exposure. Oecologia 22:229-250
Bhaud M (1998) The spreading potential of polychaete larvae does not predict adult distributions; consequences for conditions of recruitment. Hydrobiologia 376:35-47

Burton RS, Feldman MW (1981) Population-genetics of Tigriopus californicus: Differentiation among neighbouring populations. Evolution 35:1192-1205

Carlton JT (1985) Trans-oceanic and interoceanic dispersal of coastal marine organisms - the biology of ballast water. Oceanogr Mar Biol Annu Rev 23:313-371

Christensen AM (1970) Feeding biology of the sea-star Astropecten irregularis Pennant. Ophelia 8:1-134

Coutts ADM, Moore KM, Hewitt C (2003) Ships' sea-chests: an overlooked transfer mechanism for non-indigenous marine species? Mar Pollut Bull 46:1510-1513

Crema R, Castelli A, Prevedelli D (1991) Long-term eutrophication effects on macrofaunal communities in Northern Adriatic Sea. Mar Pollut Bull 22:503-508

Creutzberg F (1986) Distribution patterns of two bivalve species (Nucula turgida, Tellina fabula) along a frontal system in the Southern North Sea. Neth J Sea Res 20:305-311

Currie DR, Parry GD (1999) Changes to benthic communities over 20 years in Port Phillip Bay, Victoria, Australia. Mar Pollut Bull 38:36-43

Dekker R, Beukema JJ (1993) Dynamics and growth of a bivalve, Abra tenuis, at the Northern edge of its distribution. J Mar Biol Assoc UK 73:497-511

De Zwaan A, Cattani O, Vitali G, Cortesi P (2001 Influence of incubation conditions on the anoxic survival of marine bivalve. Static and semi-static incubations. Mar Ecol Prog Ser 211:169-179

Diaz RJ, Rosenberg R (1995) Marine benthic hypoxia: a review of its ecological effects and the behavioural responses of macrobenthic fauna. Oceanogr Mar Biol Annu Rev 33:245-303

Giacobbe S, Rinelli R (2002) Corbula gibba (Mollusca: Bivalvia) death assemblages in Augusta harbour, Mediterranean Sea. J Mar Biol Assoc UK 82:265-268

Grant J, Thorpe B (1991) Effects of suspended sediment on growth, respiration, and excretion of the soft-shell clam (Mya arenaria). Can J Fish Aquat Sci 48:1285-1292

Green J (1957) The growth of Scrobicularia plana (Da Costa) in the Gwendraeth Estuary. J Mar Biol Assoc UK 36:41-47

Hamburger K, Mohlenberg F, Randlov A, Riisgard HU (1983) Size, oxygen-consumption and growth in the mussel Mytilus edulis. Mar Biol 75:303-306

Heilmayer O, Brey T, Storch D (2004) Population dynamics and metabolism of Aequipecten opercularis (L.) from the western English Channel (Roscoff, France). J Sea Res 52:33-44

Heipel DA, Bishop JDD, Brand AR, Thorpe JP (1998) Population genetic differentiation of the great scallop Pecten maximus in western Britain investigated by randomly amplified polymorphic DNA. Mar Ecol Prog Ser 162: 163-171

Highsmith R (1985) Floating and algal rafting as potential dispersal mechanisms in brooding invertebrates. Mar Ecol Prog Ser 25:169-179

Holmes SP, Miller N, Weber A (2002) The respiration and hypoxic tolerance of Nucula nitidosa and N. nucleus: factors responsible for determining their distribution? J Mar Biol Assoc UK 82:971-981

Holmes SP, Witbaard R, Van der Meer J (2003) Phenotypic and genotypic population differentiation in the bivalve mollusc Arctica islandica (L.): results from RAPD analysis. Mar Ecol Prog Ser 254:163-176

Holmes SP, Dekker R, Williams ID (2004) Population dynamics and genetic differentiation in the bivalve mollusc Abra 
tenuis (Montagu): a species with aplanic dispersal. Mar Ecol Prog Ser 268:131-140

Hrsbrenko M (1981) Population studies of Corbula gibba (Olivi), Bivalvia, Corbulidae, in the Northern Adriatic Sea. J Molluscan Stud 47:17-24

Hughes RN (1970) An energy budget for a tidal-flat population of Bivalve Scrobicularia plana (Dacosta). J Anim Ecol 39:357-368

Jensen JN (1990) Increased abundance and growth of the suspension-feeding bivalve Corbula gibba in a shallow part of the eutrophic limfjord, Denmark. Neth J Sea Res 27:101-108

Johannesson K (1988) The paradox of Rockall: why is a brooding gastropod (Littorina saxatilis) more widespread than one having a larval dispersal stage (L. littorea)? Mar Biol 99:507-513

Jones NS (1956) The fauna and biomass of a muddy sand deposit off Port Erin, Isle of Man. J Anim Ecol 25:217-252

Jorgensen CB (1946) Lamellibranchia. Medd Komm Dan Fisk-Havunders Ser Plankton 4:1-523

Kennedy VS, Mihursky JA (1972) Effects of temperature on the respiratory metabolism of three Chesapeake Bay bivalves. Chesapeake Sci 13:1-22

Kiørboe T, Mohlenberg F (1981) Particle selection in suspension-feeding bivalves. Mar Ecol Prog Ser 5:291-296

Kleiber M (1961) The fire of life: an introduction to animal energetics. Wiley, New York

Laureta LV (1986) Trophic dynamics of a benthic community, with particular reference to the ecological energetics of Corbula gibba (Olivi). $\mathrm{PhD}$ thesis, University of Liverpool

McMahon RF, Wilson JG (1981) Seasonal respiratory responses to temperature and hypoxia in relation to burrowing depth in three intertidal bivalves. J Therm Biol 6: 267-277

Moodley L, Heip CHR, Middelburg JJ (1998) Benthic activity in sediments of the northwestern Adriatic Sea: sediment oxygen consumption, macro- and meiofauna dynamics. J Sea Res 40:263-280

Moore HB (1931) The muds of the Clyde sea area. III. Chemical and physical conditions; rate and nature of sedimentation and fauna. J Mar Biol Assoc UK 17:325-358

Moore PH (1977) Additions to the littoral fauna of Rockall, with description of Araeolaimus Penelope sp. nov. (Nematoda: Axonolaimidae). J Mar Biol Assoc UK 57:191-200

Muus K (1973) Settlement, growth and mortality of young bivalves in the Oresund. Ophelia 12:79-116

Newell CR, Hidu H (1982) The effects of sediment type on growth-rate and shell allometry in the soft shelled clam Mya arenaria L. J Exp Mar Biol Ecol 65:285-295

Newell RC, Northcroft HR (1967) A re-interpretation of effect of temperature on metabolism of certain marine invertebrates. J Zoo 151:277-278

Olivier F, Vallet C, Dauvin J, Retiere C (1996) Drifting in postlarvae and juveniles in an Abra alba (Wood) community of the eastern part of the Bay of Seine (English Channel). J Exp Mar Biol Ecol 199:89-109

Pearson TH, Rosenberg R (1978) Macrobenthic succession in relation to organic enrichment and pollution of the marine environment. Oceanogr Mar Biol Annu Rev 16:229-311

Pechenik JA (1999) On the advantages and disadvantages of larval stages in benthic marine invertebrate life cycles. Mar Ecol Prog Ser 177:269-297

Pisarovic A, Meixner VZ, Benc S (2000) A contribution to the knowledge of bivalve Corbula gibba (Olivi, 1792) behaviour, oxygen consumption and anaerobic metabolism. Period Biol 102:303-307

Editorial responsibility: Otto Kinne (Editor-in-Chief), Oldendorf/Luhe, Germany
Pruvot C, Empis A, Diainaut-Courtos N (2000) New record of the mollusc Corbula gibba (Olivi, 1792) in the muddy sands of Dunkirk harbour (North Sea). Bull Soc Zool Fr $125: 75-82$

Rachor E (1976) Structure, dynamics and productivity of a population of Nucula nitidosa (Bivalvia: Protobranchia). Ber Dtsch Wiss Komm Meeresforsch 24:296-331

Riisgard HU (1998) No foundation of a '3/4 power scaling law' for respiration in biology. Ecol Lett 1:71-73

Rosenberg R (1977) Benthic macro-faunal dynamics, production, and dispersion in an oxygen-deficient estuary of West Sweden. J Exp Mar Biol Ecol 26:107-133

Rueda JL, Fernandez-Casado M, Salas C, Gofas S (2001) Seasonality in a taxocoenosis of molluscs from soft bottoms in the Bay of Cadiz (southern Spain). J Mar Biol Assoc UK 81: 903-912

Rygg B (1970) Studies on Cerastoderma edule (L.) and Cerastoderma glaucum (Poiret). Sarsia 43:65-68

Schneider S, Roessli D, Excoffier L (2000) Arlequin ver. 2.000: a tool for population genetics data analysis. Genetics and Biometry Laboratory, University of Geneva

Slatkin M (1985) Gene flow in natural populations. Annu Rev Ecol Syst 16:393-430

Swofford DL (2002) PAUP*: phylogenetic analysis using parsimony ( ${ }^{*}$ and other methods). Version 4.10. Sinauer Associates, Sunderland, MA

Talman SG, Keough MJ (2001) Impact of an exotic clam, Corbula gibba, on the commercial scallop Pecten fumatus in Port Phillip Bay, south-east Australia: evidence of resource-restricted growth in a subtidal environment. Mar Ecol Prog Ser 221:135-143

Taylor AC (1974) Aspects of the respiratory physiology of the bivalve Arctica islandica (L.). PhD thesis, University of Liverpool

Taylor AC, Davenport J, Allen JA (1995) Anoxic survival, oxygen-consumption and hemocyanin characteristics in the protobranch bivalve Nucula sulcata Bronn. Comp Biochem Physiol 112:333-338

Tebble N (1966) British bivalve seashells. British Museum (Natural History), London

Theede H (1973) Comparative studies on the influence of oxygen deficiency and hydrogen sulphide on marine bottom invertebrates. Neth J Sea Res 7:244-252

Theede H, Ponat A, Hiroki K, Schliepe C (1969) Studies on resistance of marine bottom invertebrates to oxygen-deficiency and hydrogen sulphide. Mar Biol 2:325-328

Theodorou AJ (1994) The ecological state of the Elefsis Bay prior to the operation of the Athens Sea outfall. Water Sci Technol 30:161-171

Thorson G (1946) Reproduction and larval development of Danish marine bottom invertebrates, with special reference to the planktonic larvae in the sound (Oresund). Medd Komm Dan Fisk-Havunders 4:1-523

Trevallion A (1965) A study of certain protobranch bivalve molluscs and an investigation on detritus. $\mathrm{PhD}$ thesis, University of Southampton, Southampton

West GB, Woodruff WH, Brown JH (2002) Allometric scaling of metabolic rate from molecules and mitrochondria to cells and mammals. Proc Natl Acad Sci USA 99:2473-2478

Widdows J (1985) Physiological responses to pollution. Mar Pollut Bull 16:129-134

Wilson RS, Heislers S, Poore GCB (1998) Changes in benthic communities of Port Phillip Bay, Australia, between 1969 and 1995. Mar Freshw Res 49:847-861

Yonge CM (1946) On the habits and adaptations of Aloidis (Corbula) gibba. J Mar Biol Assoc UK 26:358-376

Submitted: May 23, 2005; Accepted: October 13, 2005

Proofs received from author(s): May 26, 2006 